\begin{tabular}{|l|c|c|c|}
\hline Jus et civitas & $\begin{array}{c}\text { Vol. VIII(LXII) } \\
\text { No. } 1 / 2021\end{array}$ & $51-56$ & $\begin{array}{c}\text { A Journal of Social and Legal } \\
\text { Studies }\end{array}$ \\
\hline
\end{tabular}

\title{
CURIOSITY AND MOTIVATION, A POSSIBLE CORRELATION
}

\section{Dragoș Grigorescu}

Petroleum - Gas University of Ploiesti, Bd. Bucharest, no. 39, Ploiesti, Romania

e-mail: dgrigorescu@upg-ploiesti.ro

DOI:10.51865/JETC.1.07

\begin{abstract}
In this introductory paper we aim to critically analyze a possible research design on the correlation between curiosity and intrinsic motivation in students. In this sense, the background of the problem will be analyzed in an introduction that will emphasize the importance of this possible correlation in the current school context dominated by the new mental organization of digital students. Then they will be analyzed among the fundamental elements of a research. First of all, the choice of appropriate research tools, which will combine qualitative and quantitative research. Secondly, it is a discussion about the purposes of researching the mentioned correlation, the basic questions, the objectives, the sample and, finally, about the ways of analyzing the data and the necessary conclusions.
\end{abstract}

Keywords: education, motivation, curiosity, education research

\section{Context}

The life experience that the school offers to all today's students in Romania or from anywhere is more complex than ever. The hectic pace of change that students have to adapt to is astonishing compared to the pace of life in schools 30 or 50 years ago. The emergence of new types of minds in the new generations, formed through the assistance of digital and virtual, include mandatory pedagogical challenges to maintain the connection between teachers and students. Challenges contain dangers and opportunities. The dangers refer primarily to mental fractures between students and teachers, against the background of the general crisis of value identity of contemporary society. This crisis is best shown by $\mathrm{T}$. Nichols, who, in a synthetic expression, says things by name, unlimited digital information, makes us more stupid. (Nichols, 2019, p. 123). Opportunities refer to the richer knowledge of human nature. Never in the history of mankind have teachers been able to get to know their students better than they do today, even before entering the classroom. Psychology, neuroscience, ethology, with their specific branches, elucidate with the means of exact science more and more mysteries about man that for centuries were the object of imagination and philosophical ingenuity. With a minimum of training, a competent teacher today knows how a child's mind and soul work and has access to scientifically accredited means of pedagogical intervention. Both the dangers and the 
opportunities described above, to limit ourselves to just a few of them, make working as an educator today a demanding experience, but at the same time motivating.

In the present research, we set out to investigate, in the current pandemic context, two extremely important components of the educational process in Romanian schools: the curiosity of high school students and their level of intrinsic motivation. Both internal traits of children make a decisive mark on school success (performance, performance), but also on the classroom environment or the well-being of students and teachers. Every teacher wants motivated and interested students in the class, as any student is concerned with finding out things that make him feel appropriate in relation to his classmates and society as a whole, or finding answers to the challenges he faces. school training period. Both teachers and students are looking for each other in this wonderful travel meeting called education, and motivation and curiosity are key ingredients for this meeting to be a success.

Research dedicated to motivation and curiosity is relatively numerous and diverse in the last hundred years, but has not stood out for the great mass of educators in the last 50 years. The grounds for this situation are in turn a distinct object of study, but in recent decades motivation has become an ever-present component in pedagogy treatises, including in Romania (Cucoș, 2017; Pânişoară, 2018). Instead, the topic of curiosity remained far from the attention of researchers. Therefore, we consider that this research covers a need to know the educational environment in general and by investigating these components, but at the same time connects the scientific educational environment in our country to current mentalities of approach and research of education in international communities. tradition.

\section{Research design}

Curiosity and motivation are internal components of students' minds, and their approach requires probing the interior of each child, so it is recommended an investigative path to start with the knowledge of subjective realities in which high school students live their lives as students, then follow a quantitative measurement to extract any regularities. The initially designed doctoral research provided for the combination of a qualitative research with a quantitative one. The compelling pandemic reality meant that the qualitative research approach, which meant a number of hours of classroom observation, interviews and other qualitative tools, could not be carried out under conditions of scientific objectivity. Therefore, we mainly used the classic tools of quantitative research through which we tried to capture as accurately as possible the levels of motivation and curiosity in the selected high school students.

The ethnographic research aimed to obtain a concrete database, extracted from the direct realities of school life, which would have facilitated the creation of a quantitative research tool adapted to these realities. In the absence of direct access, we resorted to standardized tools that proved both their validity and scientific objectivity, but especially were designed in such a way that by construction they allowed an adaptation to very diverse school environments. For both curiosity and intrinsic motivation, the holders of the rights to use the tools invited to test them in as diverse situations and environments as possible with the obvious aim of increasing the validity and accuracy for each of these tools. Both standardized questionnaires have reached a threshold of scientific maturity and have been applied systematically for several years in schools in different countries. In the case of 
internal motivation we used one of the four variants of the I.M.I. (Intrinsic Motivation Inventory) which has enjoyed considerable success over more than two decades, being an integral part of the framework theory of self-determination (S.D.T.). For curiosity, we chose the most relevant variant for the school environment, the test of the five dimensions of curiosity (5D.CR - 5 Dimensions of Curiosity Revised), also applied in American schools for several years, a process which has seen improved variants and revised.

It is important to emphasize that both tests are the result of a selection made successively several years in a row, and the criteria that formed the basis of these selections were among the requirements assumed in this research such as: application and specific addressing on students and less on a non-school audience, relevance to school practice, compliance with the restrictive conditions of research ethics with emphasis on parental consent and mental well-being of the minors involved (minimum discomfort in completing the questionnaire), respect for cultural diversity and local habits, ease in application of tools (interaction as little as possible between researcher and students online environment), full transparency of the process of data collection, recording and interpretation (possibility to restore statistical interpretation).

The two framework questionnaires, available online in open source mode, have a different structure. The I.M.I. has a first set of fundamental items that aim at intrinsic motivation in general, and another four sets of items that are dedicated to a more precise investigation of internal motivation in relation to various benchmarks, for example: 1. motivation to learn for a task or an exam; 2. the motivation measured in relation to the experience (analysis) with a text; 3 . the motivation resulting from questioning the subjects 'impressions about solving some tasks and 4. the motivation relative to the subjects' perceptions about learning / effort / commitment. The 5D.C.R. (Kashdan, 2019) consists of 5 groups of questions focused on:

a. joyful exploration (exploration researched from the perspective of the emotional state associated with the experience of knowledge, eg solving a mystery or finding a solution to a problem - joyous exploration);

b. sensitivity to the unknown, items that measure how much are disturbed, in our case students subjects of incomplete data, missing parts, unknown, etc. - deprivation sensitivity;

c. stress tolerance, a set of items that measure the negative impact of the exploration experience, student resilience, management of inner effort associated with the unknown or problems - stress tolerance;

d. social curiosity, a group of items dedicated to the relationship of subjects, learning or discovery in teams or groups, managing their own behavior and social adaptability by understanding the behavior of others - social curiosity;

e. the search for emotion, a group of items that aims to measure the availability to risk or the risk profile corresponding to the exploration of the unknown, planning and the sense of adventure and new things, the unpredictability of social relationships - thrill seeking)

Finally, a single questionnaire consisting of 36 items was reached, the first 18 dedicated to curiosity research, which plays the role of an independent variable, and the next 18 questions aim at measuring intrinsic motivation, with the role of a dependent variable. 
For the accuracy of the results, we translated and adapted the items from the original questionnaire in relation to the specifics of the psychological and cognitive profile of the high school students, including the language used. In this way we obtained short closed questions, easy to read and understand, formulated in a colloquial language oriented towards a casual and familiar reporting from the students.

\section{The purpose of the research}

Through comparative research on intrinsic curiosity and motivation, we aim to show that we can have internally and long-term motivated students if we adequately stimulate students' native curiosity. In general, although it is admitted that intrinsic motivation is extremely important for the whole educational process and even methodological suggestions are offered to stimulate it, in educational practice it is not among the assumed teaching tasks for which resources are allocated. Indeed, although an intrinsically motivated student is indisputably an optimal partner for the teacher, he is not so easy to obtain. Moreover, we consider that stimulating curiosity seen as a way to motivate students internally, respects or at least can be easily folded on the teaching methods used intensively in the Romanian school environment, without the need for psychological interventions, no less useful, but perhaps more difficult to implement. The enormous advantage of stimulating curiosity is that the teacher responds to a native and instinctual inner need of the student, the need for exploration, leaving only the role of orchestra this need under professional conditions. Finally, we hope that after this research, teachers will have a way to manage the long-term motivation of students.

\section{Research questions}

Any research starts from the researcher's curiosity. Scientific research itself is primarily the result of the researcher's need to know. The question is the spark of any research, it best expresses the need for exploration. Philosophy has its origin, according to Aristotle, in wonder. Astonishment in front of the world shaped the philosophical investigation and later the scientific one. The questions of this research center around students' curiosity and inner motivation. Being a quantitative research, adapted to the distance research of students, we wanted to know how and how much students in the selected group show their curiosity and motivation in relation to learning for exams, theses or tests.

By exams we mean the national assessment exam that the 8th grade students were to take, and by tests or theses, we mean all the stages of the end-of-year assessment process that the 7th grade students took. during the study, respectively between 1 and 16 June 2021 .

The fundamental questions of this study can be articulated in descending order, from general to particular, as follows:

- How curious and motivated are the high school students in the sample?

- How can students' internal motivation be stimulated based on their basic needs?

- Does the level of intrinsic motivation vary if the curiosity in turn undergoes changes?

- Is there a relevant positive correlative link between curiosity and intrinsic motivation? 

learn?

- If we stimulate students' curiosity, then will they become more motivated to

- What is the perception of high school students compared to learning for exams?

- Can the learning experience be a pleasant one for high school students?

\section{General objectives}

The main objective of the research is to show how important curiosity is for the whole educational process. The innate need of students to learn about the things around them is an important capital that is still insufficiently exploited by teachers. Another goal of the research is to show that in order to have more motivated students we need to pay attention to how we can stimulate and nurture their curiosity.

\section{Secondary objectives}

Let's explore the level of native curiosity of the high school students in the sample sample are

Let's investigate how internally motivated the middle school students in the

Let's explore how students receive the learning and assessment experience

Let's investigate the emotional context associated by students' learning experience for exams

\section{Research hypothesis}

The research hypothesis is formulated by highlighting the role of variables:

If we stimulate students' native curiosity, then they will become more intrinsically motivated.

Secondary or additional hypotheses can be formulated as follows:

If we stimulate the students' native curiosity, then they will have better school results (better results of exams / tests)

If the students are more curious, then learning / assimilation will be done faster / easier.

If students are (more) intrinsically motivated, then they will be more pronounced.

\section{The sample}

The first criterion for selecting the sample was an analysis of studies dedicated to school cycles (primary, secondary and high school) which highlighted an unbalanced situation between them. Thus, most studies, meaning scientific articles, bachelor's or master's theses were dedicated to the primary and high school cycle, while for the gymnasium level were the fewest studies. For example, from consulting two international databases, Jstore and Ceeol, a search for a comparative keyword between primary school, middle school and high school was sufficient. The results were as follows:

Ceeol: studies dedicated to primary education 2297, gymnasium 7, high school 2378 Jstore: primary 1,034,985, gymnasium 27,185 , high school 2,182,104

The following criterion followed the distribution by classes, in the range of 5 th grade to 8th grade, but favoring the final grades, 7 th and 8 th, because they have a higher number 
of tests or exams. Then we followed a diversified dispersion of schools in terms of the distinction between central urban, peripheral urban, respectively large urban (Ploiești), small urban (Vălenii de Munte, Băicoi, Sinaia, Bușteni,) and rural.

\section{Preliminary conclusions}

Both the curiosity, through all the analyzed aspects, and the intrinsic motivation are in the interviewed students in an important correlation degree and strongly impact the students' commitment for exams or different tasks. Moreover, the results entitle us to highlight the importance of curiosity as a means of stimulating the intrinsic motivation of preadolescents. On the other hand, the accumulated data outline an image of the broader context of school learning, for example how students feel the learning experience for exams in terms of emotional involvement, cognitive stimulation, students' well-being. We have a picture of the relationship between extrinsic motivation - students learn with a sense of obligation - and intrinsic motivation to learn to experience curiosity.

\section{Bibliography}

1. Cucoș, C. 2014. Pedagogie. Editia a III-a, Polirom, Iași.

2. Pânișoară, G. 2019. Psihologia învățării. Cum învață copiii și adulții? Editura Polirom, Iaș.i

3. https://selfdeterminationtheory.org/intrinsic-motivation-inventory/

4. Kashdan, Todd \& Disabato, David \& Goodman, Fallon \& Mcknight, Patrick. (2019). The Five-Dimensional Curiosity Scale Revised (5DCR): Briefer subscales while separating general overt and covert social curiosity.

5. Nichols, T. (2017) The Death of Expertise: the Campaign against Established Knowledge and Why It Matters, first edition Oxford University Press

\section{Curiozitate și motivație, o posibilă corelație}

\section{Rezumat}

În această lucrare introductivă ne propunem analiza critică a unui posibil design de cercetare privind corelația dintre curiozitate și motivația intrinsecă la elevii. În acest sens se vor analiza fondul problemei intr-o introducere care va sublinia importanța acestei posibile corelații în contextual școlar actual dominat de noua organizare mentală a elevilor digitali. Apoi se vor analiza pe rând elementele fundamentale ale unei cercetări. In primul rând alegerea unor instrumente adecvate de cercetare, care vor îmbina cercetarea calitativă cu cea cantitativă. In al doilea rând e vorba despre o discuție despre scopul cercetării corelației amintite, întrebările de bază, obiectivele, eșantionul și, în cele din urmă despre modalități de analiză a datelor și concluziile care se impun. 